\title{
The association between urinary kidney injury molecule 1 and urinary cadmium in elderly during long-term, low-dose cadmium exposure: a pilot study
}

Valérie Pennemans ${ }^{1 *}$, Liesbeth M De Winter ${ }^{1}$, Elke Munters $^{2}$, Tim S Nawrot ${ }^{2,3}$, Emmy Van Kerkhove $^{2}$, Jean-Michel Rigo ${ }^{1}$, Carmen Reynders ${ }^{4}$, Harrie Dewitte ${ }^{5,6}$, Robert Carleer ${ }^{2}$, Joris Penders ${ }^{1,4+}$ and Quirine Swennen ${ }^{1+}$

\begin{abstract}
Background: Urinary kidney injury molecule 1 is a recently discovered early biomarker for renal damage that has been proven to be correlated to urinary cadmium in rats. However, so far the association between urinary cadmium and kidney injury molecule 1 in humans after long-term, low-dose cadmium exposure has not been studied.

Methods: We collected urine and blood samples from 153 non-smoking men and women aged 60+, living in an area with moderate cadmium pollution from a non-ferrous metal plant for a significant period. Urinary cadmium and urinary kidney injury molecule 1 as well as other renal biomarkers (alpha1-microglobulin, beta2-microglobulin, blood urea nitrogen, urinary proteins and microalbumin) were assessed.

Results: Both before $(r=0.20 ; p=0.01)$ and after (partial $r=0.32 ; p<0.0001)$ adjustment for creatinine, age, sex, past smoking, socio-economic status and body mass index, urinary kidney injury molecule 1 correlated with urinary cadmium concentrations. No significant association was found between the other studied renal biomarkers and urinary cadmium.

Conclusions: We showed that urinary kidney injury molecule 1 levels are positively correlated with urinary cadmium concentration in an elderly population after long-term, low-dose exposure to cadmium, while other classical markers do not show an association. Therefore, urinary kidney injury molecule 1 might be considered as a biomarker for early-stage metal-induced kidney injury by cadmium.
\end{abstract}

Keywords: kidney injury molecule 1, cadmium, renal biomarkers, toxicity, chronic, kidney

\section{Background}

Cadmium (Cd) is an ever-present and global environmental pollutant [1]. Current $\mathrm{Cd}$ emission has been drastically reduced, but $\mathrm{Cd}$ continues to be a health hazard, because historically accumulated $\mathrm{Cd}$ cannot be degraded and its half-life in the body is long (10-30 years) [2]. Next to the bone [3], a main target for chronic, low-level $\mathrm{Cd}$ exposure is the kidney, leading to

\footnotetext{
* Correspondence: Valerie.pennemans@uhasselt.be

† Contributed equally

'Biomedical Research Institute, Hasselt University and transnational University Limburg, School of Life Sciences, Diepenbeek, Belgium

Full list of author information is available at the end of the article
}

proximal tubule dysfunction $[2,4,5]$. Tubular dysfunction causes polyuria and low molecular weight proteinuria and some of these urinary proteins, e.g. $\alpha-1$ microglobulin $(\alpha 1 \mathrm{M}-\mathrm{U})[6], \beta-2$ microglobulin $(\beta 2 \mathrm{M}-\mathrm{U})[7,8]$ and clara cell protein-16 (CC-16-U)[9] are used as urinary biomarkers of the early stages of $\mathrm{Cd}$ nephrotoxicity. In other studies, Cd toxicity is monitored by the Cd-binding protein metallothionein in urine $[8,10,11], \mathrm{N}$-acetylbeta-glucosaminidase (NAG) $[7,8]$ or even urinary $\mathrm{Cd}$ itself $[7,11-13]$. Although these renal biomarkers are widely used, questions arose concerning specificity and sensitivity $[6,9,11,14-17]$. There clearly is a need for an

\section{C) Biomed Central}


early and stable biomarker for proximal tubule damage caused by Cd.

Kidney injury molecule 1 (KIM-1), originally discovered by Ichimura et al., is a type 1 membrane glycoprotein found on renal proximal tubule epithelial cells. It contains in its extracellular portion a unique 6-cysteine immunoglobulin-like domain and a mucin-domain [18]. An intracellular highly conserved tyrosine kinase phosphorylation motif is a strong indicator that KIM-1 is a cell signaling molecule [19].

KIM-1 expression is induced in a variety of renal diseases, whereas in healthy kidney tissue KIM-1 is virtually undetectable $[18,20]$. In the case of kidney damage, KIM-1 is expressed on the apical membrane followed by cleavage of the ectodomain $(90 \mathrm{kDa})$ which is released in the urine in rodents $[18,19,21-24]$ and in humans [25-28]. KIM-1 is upregulated in the proximal tubule during dedifferentiation of the kidney epithelium, an early manifestation in response to damage [29].

In rats, Prozialeck et al. showed that KIM-1 is a very early urinary marker for Cd-induced kidney injury [23]. They showed that KIM-1 was elevated before other urinary biomarkers of $\mathrm{Cd}$ nephrotoxicity, such as metallothionein, CC-16-U, proteinuria, $\alpha$-glutathione-S-transferase $(\alpha-G S T), N A G$ and Cd itself $[23,30]$. Moreover they showed that the Cd-induced increase in KIM-1 expression can be detected before signs of necrosis appear and when there is only a modest level of apoptosis in the proximal tubule [29].

It has been well established in humans that KIM-1 appears in the urine at an early stage in kidney damage and also, that $\mathrm{Cd}$ affects proximal tubule function when the $\mathrm{Cd}$ burden is high. Cd triggers the expression of KIM-1 at a very early stage in animal models [31]. The aim of the present pilot study is to assess the appearance of urinary KIM-1 after long-term, low-dose Cd exposure in humans, because, to our knowledge, this has not been investigated in the population.

\section{Methods}

\section{Study population and sample collection}

The total population $(n=3069)$ of the general practice in Genk is registered in the framework of a registration network for family practices in Flanders (INTEGO) [32]. The study area is representative of the total population. Non-smoking men and women, 60 to 80 years old, with no acute infection at enrolment and no history of malignancies, were selected in the southern region of Genk from a quarter adjacent to an industrial area where a non-ferrous metal plant, a major motor company and a power station are located and which is crossed by multiple highroads. Sampling was combined with the annual influenza vaccination at a local doctor's practice. Eligible people were notified in advance by letter. Of those that routinely are advised for influenza vaccination, approximately $86 \%$ joined the vaccination program. Of those that were eligible, 154 were recruited, and $99 \%$ agreed to participate in our study. Of the 153 persons that agreed to participate (79 women; mean age $71 \mathrm{yr}$ and 74 men; mean age $70 \mathrm{yr}$ ), for one person no urinary sample was collected and this person was not included in the analyses. Personal information was processed anonymously in conformity with privacy policy. Informed consent was obtained from all participants and the study was approved by the ethics committee of the Ziekenhuis Oost-Limburg (ZOL), Belgium. Questionnaires were administered to assess lifestyle, profession, education, past smoking status, as well as data on age, weight and gender. Family income was given as net monthly overall family income and subdivided into low $(<1500 €)$, medium $(1500 €-3000 €)$ and high $(>3000 €)$ family income. Education was coded as low (primary school), medium (high school) and high (university). Past smoking was quantified as pack years by multiplying the number of packs of cigarettes smoked per day by the number of years the person has smoked. Finally, individual medical backgrounds were used to determine possible interference of drug administration or diseases, with kidney function. Second morning urine samples and blood samples were collected from all participants. Samples were aliquoted (6 $\times 2 \mathrm{ml}$ ), stored on ice for a maximum of four hours and subsequently frozen at $-80^{\circ} \mathrm{C}$.

\section{Routine analyses and renal biomarker measurements}

Routine analyses of the urine samples were performed in the clinical laboratory of the regional hospital ZOL in Genk. Using an automated analyzer (Modular ${ }^{\circledR}$ P800ISE900 System, Roche Diagnostics; Mannheim, Germany), the following urinary analyses were performed, according to manufacturer's instructions: creatinine according to the kinetic Jaffe method (compensated, rate blanked), total protein by a colorimetric biuret test and $\alpha 1 \mathrm{M}-\mathrm{U}$ based on immunological agglutination. $\beta 2 \mathrm{M}-\mathrm{U}$ was determined by particle-enhanced immunonephelometry using the BN ProSpec (Siemens Healthcare Diagnostics; Marburg, Germany). Microalbumin was nephelometrically determined (Immage ${ }^{\circledR}$ Immunochemistry System, Beckman Coulter; Suarlee, Belgium). Blood urea and serum creatinine were measured following the same assays as with the urinary analyses. BUN (blood urea nitrogen) was determined as blood urea times two (covering the molar mass of the two nitrogens). Urinary KIM-1 was analyzed by a commercially available sandwich ELISA: Human TIM-1/KIM-1/HAVCR Duoset (R\&D Systems; Abingdon, U.K.), validated by Chaturvedi et al. [33]. The assay procedure was performed according to the prescriptions of the manufacturer. When 
necessary, samples were adjusted to $\mathrm{pH} 7.0$ before measurement [34]. The optical density was determined with a fluorescence microplate reader (FLUOstar OPTIMA, BMG Labtechnologies; Offenburg, Germany), set to 450 $\mathrm{nm}$ with a wavelength correction at $540 \mathrm{~nm}$. All samples were measured in duplicate.

\section{Urinary Cd analyses}

$\mathrm{Cd}$ concentrations in urine were analyzed by means of inductively coupled plasma mass spectrometry (ICP-MS) using the ELAN ${ }^{\circledR}$ DRC-e (Axial Field ${ }^{\text {TM }}$ Technology, Perkin Elmer SCIEX; Zaventem, Belgium). Urine samples and standards were diluted 1:10 in 1\% nitric acid.

\section{Statistical analyses}

For database management and statistical analyses, SAS Software version 9.1 (version 9.1, SAS Institute Inc, Cary (NC), USA) and GraphPad Prism 5.01 (GraphPad Software Inc, La Jolla (CA), USA) were used. Non-normally distributed data were log transformed. For comparison of means and proportions, we applied Student's t-test and the $\chi^{2}$-statistic, respectively. We investigated associations between markers of kidney function and urinary cadmium using Pearson's correlation and multiple linear regression. Estimated effect sizes and 95\% CI were calculated from linear regression coefficients for a two-fold increase in urinary $\mathrm{Cd}$. A priori three models were chosen: model 1 shows unadjusted data, in model 2 , results are adjusted for creatinine, sex, age, past smoking, body mass index (BMI) and socio-economic status (SES; based on educational degree and monthly family income), while in model 3 data are adjusted for sex, age, past smoking, BMI and SES and given as function of creatinine. When residuals are calculated (figures), we adjusted the different parameters for creatinine, sex, age, past smoking, BMI and SES, in order to remove these potential confounding factors from the association. Correlations were considered significant when $\mathrm{p}<0.05$. All tests were two-sided.

\section{Results}

The study population consists of 153 participants (52\% women) with a mean age of 71 years. Patient characteristics can be found in table 1. From all the participants, of the $54 \%$ that have ever smoked there was a significant difference between men and women (75\% and 35\% respectively, $\mathrm{p}<0.0001)$. Those who had smoked in the past had an average of 18 pack years. The average distance between their residence and the heavy metal industrial zone was $2743 \mathrm{~m}$, while the mean distance to the two main roads was $294 \mathrm{~m}$ and $562 \mathrm{~m}$. Participants have lived at their current addresses for a mean period of 36 years (range: 3 to 75 years). Geometric mean urinary Cd level was $0.76 \mu \mathrm{g} / \mathrm{g}$ creatinine. Geometric mean
Table 1 Participants characteristics

\begin{tabular}{|c|c|}
\hline Characteristics & $\begin{array}{l}\text { Total group } \\
(n=153)\end{array}$ \\
\hline \multicolumn{2}{|l|}{ Anthropometrics } \\
\hline Sex, female & 79 (52\%) \\
\hline Age, years & $71 \pm 4.5$ \\
\hline $\mathrm{BMI}, \mathrm{kg} / \mathrm{m}^{2}$ & $27.2 \pm 4.3$ \\
\hline \multicolumn{2}{|l|}{ Socio-economic status*o } \\
\hline Low & $62(41 \%)$ \\
\hline Median & 59 (39\%) \\
\hline High & $29(19 \%)$ \\
\hline \multicolumn{2}{|l|}{ Familial income, per month ${ }^{\circ}$} \\
\hline$<1500 €$ & $71(47 \%)$ \\
\hline $1500-3000 €$ & 77 (51\%) \\
\hline$>3000 €$ & $2(1 \%)$ \\
\hline \multicolumn{2}{|l|}{ Smoking status } \\
\hline Ex-smoker $^{\dagger}$ & $81(54 \%)$ \\
\hline Never smoked ${ }^{\dagger}$ & $68(46 \%)$ \\
\hline Exposure to environmental tobacco smoke & $61(48 \%)$ \\
\hline \multicolumn{2}{|l|}{ Use of medication ${ }^{\S}$} \\
\hline Antiplatelet medication & $13(9 \%)$ \\
\hline Statins & $81(53 \%)$ \\
\hline ACE inhibitor & $27(18 \%)$ \\
\hline Insulin & $5(3 \%)$ \\
\hline Antidiabetic medication & $19(13 \%)$ \\
\hline NSAID & $23(15 \%)$ \\
\hline \multicolumn{2}{|l|}{ Blood analyses } \\
\hline Hemoglobin, g/dl & $14.17 \pm 1.24$ \\
\hline Red blood cells, $10^{6} /\left.\mu\right|^{\prime \prime}$ & $4.75(4.68-4.82)$ \\
\hline White blood cells, $10^{3} / \mu l^{\prime \prime}$ & $6.58(5.76-7.53)$ \\
\hline Neutrophils, \%" & $55.10(53.60-56.66)$ \\
\hline Lymphocytes, \%" & $29.70(28.35-31.12)$ \\
\hline Monocytes, \%" & $6.52(5.76-7.53)$ \\
\hline Eosinophils, \%" & $2.79(2.39-3.25)$ \\
\hline Ferritin, ng/ml" & $121.9(108.0-137.6)$ \\
\hline \multicolumn{2}{|l|}{ CRP, mg/dl } \\
\hline Creatinine, mg/dl" & $0.86(0.83-0.89)$ \\
\hline Glucose, mg/d" & $99.95(96.50-103.50)$ \\
\hline Cholesterol, mg/dl & $200.7 \pm 37.26$ \\
\hline $\mathrm{HDL}, \mathrm{mg} / \mathrm{dl}$ & $56.64(54.04-59.37)$ \\
\hline $\mathrm{LDL}, \mathrm{mg} / \mathrm{dl}$ & $114.4 \pm 34.48$ \\
\hline Triglycerides, mg/dl" & $122.1(112.8-132.1)$ \\
\hline
\end{tabular}

Data are arithmetic mean \pm standard deviation or absolute number (percentage of study population);

" data which are not normally distributed and for which geometric mean (95\% confidence interval) is given.

*Based on educational degree; ${ }^{\circ} n=150 ;{ }^{\dagger} n=149 ;{ }^{\S} n=152 ;{ }^{n} n=126$

of the urinary KIM-1 concentrations as well as the mean concentrations of other renal biomarkers $(\beta 2 \mathrm{M}-\mathrm{U}$, $\alpha 1 \mathrm{M}-\mathrm{U}, \mathrm{BUN}$, urinary proteins, microalbuminuria) and creatinine are given in table 2 .

Urinary KIM-1 was not influenced by gender ( $\mathrm{p}=$ $0.83)$, age $(p=0.08)$, distance between housing and 
Table 2 Mean urinary cadmium and renal biomarker values

\begin{tabular}{|c|c|}
\hline & Mean $(95 \% \mathrm{Cl})$ \\
\hline Cadmium, $\mu \mathrm{g} / \mathrm{l} \dagger$ & $0.80(0.73-0.88)$ \\
\hline Cadmium/creatinine, $\mu \mathrm{g} / \mathrm{g}$ creat $\dagger$ & $0.76(0.70-0.84)$ \\
\hline $\mathrm{KIM}-1, \mathrm{pg} / \mathrm{ml}^{*}$ & $569(498-651)$ \\
\hline KIM-1/creatinine, $\mu \mathrm{g} / \mathrm{g}$ creat $^{*}$ & $0.55(0.49-0.62)$ \\
\hline a1-microglobulin, mg/l† & $3.19(2.58-3.91)$ \\
\hline a1-microglobulin/creatinine, mg/g creat† & $2.97(2.42-3.64)$ \\
\hline Proteins, mg//* & $71.80(63.81-80.80)$ \\
\hline Proteins/creatinine, mg/g creat* & $66.61(59.99-73.95)$ \\
\hline Albumin, $\mathrm{mg} /\left.\mathrm{dl}\right|^{*}$ & $8.73(7.46-10.21)$ \\
\hline Albumin/creatinine, mg/g creat* & $8.43(7.32-9.70)$ \\
\hline$\beta 2$-microglobulin, mg/lf & $0.12(0.11-0.13)$ \\
\hline$\beta 2$-microglobulin/creatinine, mg/g creat $\neq$ & $0.12(0.11-0.13)$ \\
\hline $\mathrm{BUN}, \mathrm{mg} / \mathrm{dl}+$ & $35.94(34.47-37.46)$ \\
\hline Urinary creatinine, $\mathrm{mg} / \mathrm{dl}^{*}$ & $104.9(96.55-114.0)$ \\
\hline
\end{tabular}

Geometric mean (95\% confidence interval) of urinary cadmium and renal biomarkers. All parameters were measured in urine; except for blood urea nitrogen, which was measured in blood. † $n=152 ;{ }^{*} n=153 ; \neq n=140$.

industrial zone $(\mathrm{p}=0.57)$, SES $(\mathrm{p}=0.40)$, past smoking $(\mathrm{p}=0.14)$ and BMI $(\mathrm{p}=0.83)$. Both before (table 3 and Figure 1) and after adjustment (table 3) for sex, age, past smoking, BMI and socio-economic status (including education and income) variables, KIM-1 correlated positively and significantly with the urinary cadmium concentration. For the other biomarkers (BUN, microalbuminuria and urinary proteins) unadjusted and adjusted multiple linear regression models showed no significant correlation between these biomarkers of kidney function and urinary $\mathrm{Cd}$ (see Figure 1 and table 3 ). Both for $\beta 2 \mathrm{M}-\mathrm{U}$ and $\alpha 1 \mathrm{M}-\mathrm{U}$ a considerable amount of urine samples that were tested $(84 \%$ and $28 \%$ respectively) were below the limit of detection, suggesting the assessments that were used were not sensitive enough. Therefore, no analysis was conducted for $\beta 2 \mathrm{M}-\mathrm{U}$ and $\alpha 1 \mathrm{M}-\mathrm{U}$ in association with $\mathrm{Cd}$.

\section{Discussion}

About a decade ago, KIM-1 was discovered in the search for molecules involved in the pathogenesis of acute kidney injury. We demonstrated among elderly a robust association between urinary KIM-1 and urinary $\mathrm{Cd}$. Depending on the biomarker of nephrotoxicity thresholds of urinary $\mathrm{Cd}$ can range from about $2.4 \mu \mathrm{g}$ $\mathrm{Cd} / \mathrm{g}$ creatinine for the onset of early biochemical alterations (e.g. hypercalciuria) to $10 \mu \mathrm{g} \mathrm{Cd} / \mathrm{g}$ creatinine for
Table 3 Estimated change (\%) in urinary biomarker levels calculated for a two-fold increase in urinary cadmium concentration

\begin{tabular}{|c|c|c|c|c|}
\hline & $\begin{array}{l}\text { Estimated effect size } \\
(\%)\end{array}$ & $95 \% \mathrm{Cl}(\%)$ & $\mathrm{R}^{2}$ & $\begin{array}{l}\mathrm{p}- \\
\text { value }\end{array}$ \\
\hline \multicolumn{5}{|l|}{ Model 1} \\
\hline $\mathrm{KIM}-1$ & 23.73 & $\begin{array}{l}6.92 \text { to } \\
43.18\end{array}$ & 0.05 & 0.005 \\
\hline Microalbumin & 4.40 & $\begin{array}{l}-13.42 \text { to } \\
25.89\end{array}$ & 0.001 & 0.65 \\
\hline Proteins & 5.66 & $\begin{array}{l}-3.52 \text { to } \\
15.71\end{array}$ & 0.01 & 0.24 \\
\hline BUN & -5.65 & $\begin{array}{l}-10.53 \text { to } \\
-0.49\end{array}$ & 0.04 & 0.03 \\
\hline \multicolumn{5}{|l|}{ Model 2} \\
\hline $\mathrm{KIM}-1$ & 39.54 & $\begin{array}{l}18.26 \text { to } \\
64.65\end{array}$ & 0.27 & 0.0001 \\
\hline Microalbumin & 4.85 & $\begin{array}{l}-14.14 \text { to } \\
28.03\end{array}$ & 0.27 & 0.64 \\
\hline Proteins & 3.15 & $\begin{array}{l}-6.26 \text { to } \\
13.52\end{array}$ & 0.49 & 0.53 \\
\hline BUN & -4.66 & $\begin{array}{l}-9.83 \text { to } \\
0.80\end{array}$ & 0.08 & 0.10 \\
\hline \multicolumn{5}{|l|}{ Model 3} \\
\hline $\mathrm{KIM}-1$ & 26.59 & $\begin{array}{l}7.82 \text { to } \\
48.62\end{array}$ & 0.13 & 0.005 \\
\hline Microalbumin & -2.80 & $\begin{array}{l}-20.42 \text { to } \\
18.78\end{array}$ & 0.09 & 0.78 \\
\hline Proteins & 0.66 & $\begin{array}{l}-8.65 \text { to } \\
10.92\end{array}$ & 0.11 & 0.89 \\
\hline BUN & -3.69 & $\begin{array}{l}-8.99 \text { to } \\
1.91\end{array}$ & 0.07 & 0.19 \\
\hline
\end{tabular}

All data were log-transformed and estimated effect size is given as \% estimated effect size calculated for a two-fold increase in urinary cadmium concentrations ( $\mu \mathrm{g} / \mathrm{g}$ creatinine) with the corresponding $95 \%$ confidence interval, $\mathrm{R}^{2}$ gives the explained variance.

Abbreviations: KIM-1, kidney injury molecule 1; BUN, blood urea nitrogen; $\mathrm{Cl}$, confidence interval

Model 1: unadjusted but given as function of creatinine

Model 2: adjusted for creatinine (except for blood urea nitrogen), sex, age, past smoking, body mass index and socio-economic status

Model 3: adjusted for sex, age, past smoking, body mass index and socioeconomic status; given as a function of creatinine.

the development of the classic tubular microproteinuria [13]. Here, we showed biochemical changes at urinary $\mathrm{Cd}$ levels below $1 \mu \mathrm{g} \mathrm{Cd} / \mathrm{g}$ creatinine.

Ichimura et al. were the first to describe KIM-1 as a type 1 membrane glycoprotein, which contains a 6 cystein immunoglobulin-like domain in its extracellular portion, and a Thr/Ser-Pro rich domain characteristic of mucin-like O-glycosylated proteins [18]. KIM-1 also has a transmembrane domain and a cytoplasmic domain, which contains a conservative tyrosine kinase phosphorylation site, indicating that KIM-1 may be a signaling molecule [19]. In healthy kidney tissue, KIM-1 is virtually undetectable whereas in the injured kidney, KIM1 expression is rapidly upregulated at the apical side of the proximal tubule $[18,21]$. This process is 


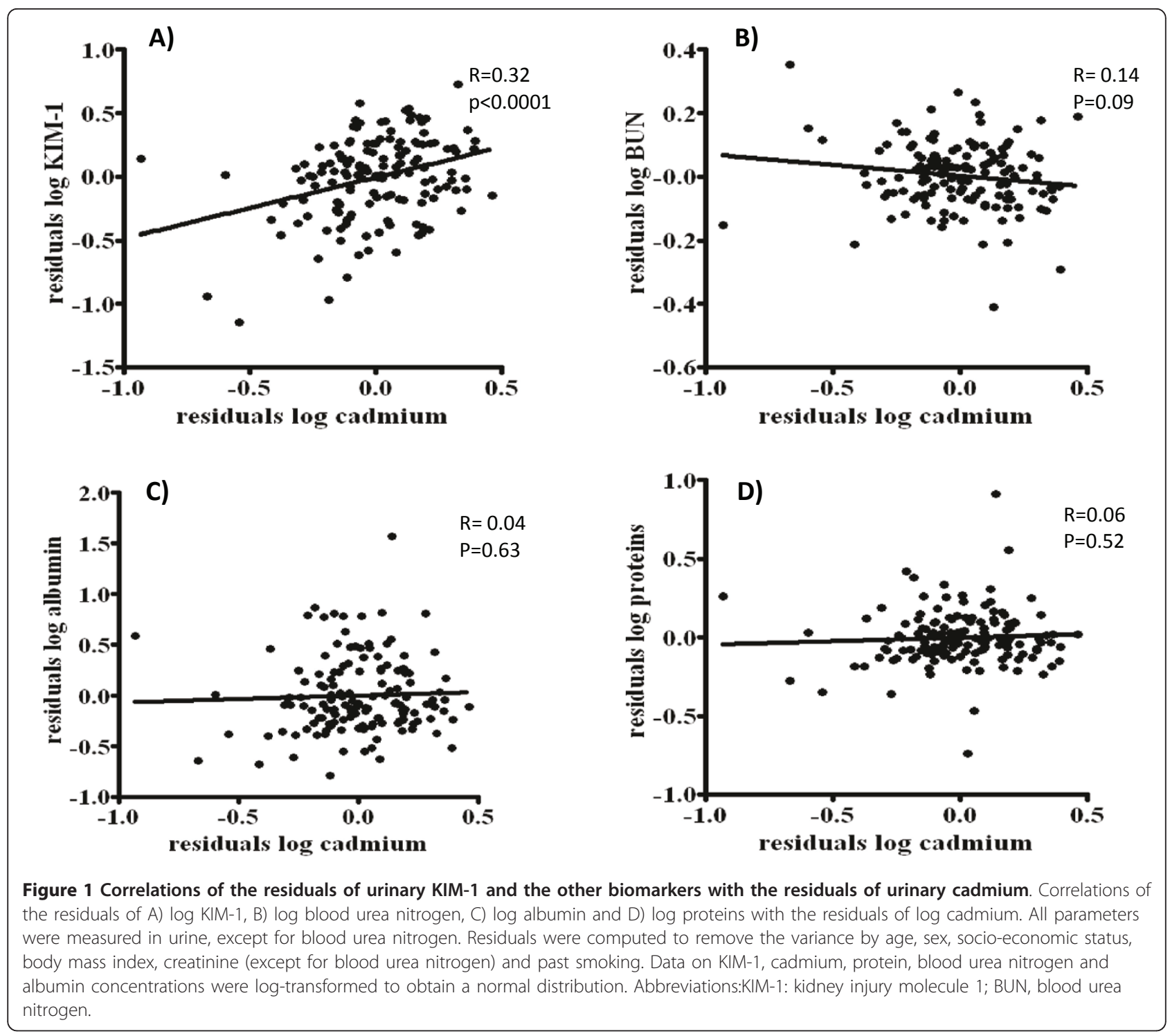

accompanied by the shedding of the extracellular domain of KIM-1 into the urine [19]. The ectodomain is stable in urine [34] and has shown to be a sensitive biomarker of renal injury induced by a variety of agents including the heavy metal Cd: Prozialeck et al. have proven KIM-1 to be a putative early biomarker for proximal tubule damage caused by high doses of $\mathrm{Cd}$ in rats, outperforming the classic biomarkers such as metallothionein, CC-16, $\alpha$-GST and urinary proteins $[23,29,30]$. In addition, KIM-1 appears before any lethal injury is detected in the proximal tubule epithelial cells [29]. Thus, using this biomarker, very early detection of cell stress may be possible, which would allow for the reversal and/or the treatment of Cd-induced kidney injury [35]. To our knowledge however, no research has ever focused on the correlation of the Cd burden and the urinary KIM-1 concentrations in humans.

Since we were mainly interested in the possible role for KIM-1 as a biomarker after long term environmental $\mathrm{Cd}$ intoxication, we chose a non-smoking elderly population living near a non-ferrous metal industrial zone in Genk for a longer period. In this region, levels of $\mathrm{Cd}$ have been reported to be higher than in other Belgian gauging regions according to the Flemish environmental agency (VMM: Mira-T indicator rapport 2008).

Both blood and urinary $\mathrm{Cd}$ are indicators of $\mathrm{Cd}$ body burden; however urinary $\mathrm{Cd}$ correlates better with the duration of exposure than does blood Cd [12,36,37], which makes it a better indicator for long-term $\mathrm{Cd}$ exposure. Therefore, we compared the urinary $\mathrm{Cd}$ 
concentrations with KIM-1 and other biomarkers of nephrotoxicity.

As shown in Figure 1, after adjustment for creatinine, sex, age, past smoking, BMI and SES, only KIM-1 was significantly correlated with Cd levels.

Urinary Cd concentration averaged below $1 \mu \mathrm{g} / \mathrm{g}$ creatinine among our population. This may explain why albuminuria, proteinuria and BUN did not correlate with urinary $\mathrm{Cd}$. These markers mainly identify later stages of Cd-induced kidney injury [38,39].

Although $\alpha 1 \mathrm{M}-\mathrm{U}$ is stable across physiological $\mathrm{pH}[40]$, its specificity is undermined by the influence of several conditions such as liver disease [15], HIV [16], mood disorders [17] and other environmental influences, for example lead exposure [41]. In contrast to $\beta 2 \mathrm{M}-\mathrm{U}$, which is degraded rapidly in acidic urine [42], urinary KIM-1 has been proven to be stable over the physiological range of urinary $\mathrm{pH}$ values [34]. Moreover, it originates from proximal tubule cells [20,43], which makes it a much more specific renal biomarker than proteins originating from other parts of the body. Prozialeck et al. found in rats that urinary KIM-1 starts to increase significantly earlier and at lower doses of $\mathrm{Cd}$ than metallothionein, $\mathrm{CC}-16$, proteins and $\alpha$-GST $[29,30,44]$. The present study corroborates this high sensitivity for human subjects.

Since KIM-1 has a high cysteine content and $\mathrm{Cd}$ is known for its high binding capacity with cystein complexes [45], future research should focus on whether this influences the correlation between urinary KIM-1 and urinary $\mathrm{Cd}$.

\section{Conclusions}

In conclusion, this pilot study shows that urinary KIM-1 levels are significantly correlated with urinary Cd levels in an elderly population after long-term, low-dose exposure to $\mathrm{Cd}$, probably indicating beginning metal-induced kidney injury. To further elucidate the exact role KIM-1 can play as a biomarker for early cadmium-induced renal damage, future research should concentrate on the comparison of KIM-1 with other biomarkers by using the most sensitive and reliable measuring techniques, with inclusion of a paired control group, living in unpolluted areas.

\section{List of abbreviations \\ Cd: cadmium; a1M-U: urinary a-1 microglobulin; a-GST: a-glutathione-S- transferase; $\beta 2 \mathrm{M}-\mathrm{U}$ : urinary $\beta-2$ microglobulin; BMI: body mass index; BUN: blood urea nitrogen; CC-16-U: urinary clara cell protein-16; Cl: confidence interval; ICP-MS: inductively coupled plasma mass spectrometry; KIM-1: kidney injury molecule 1; NAG: N-acetyl-beta-glucosaminidase; SES: socio- economic status; ZOL: Ziekenhuis Oost-Limburg.}

\section{Acknowledgements}

The Environmental Health Research at Hasselt University is supported by a grant from the Flemish Scientific Fund (Krediet aan navorsers) [1.5.158.09. N.00], and transnational University Fund (tUL-impulse).

\section{Author details}

${ }^{1}$ Biomedical Research Institute, Hasselt University and transnational University Limburg, School of Life Sciences, Diepenbeek, Belgium. ${ }^{2}$ Centre for Environmental Sciences, Hasselt University and transnational University Limburg, School of Life Sciences, Diepenbeek, Belgium. ${ }^{3}$ Occupational \& Environmental Medicine, Leuven University (KULeuven), Leuven, Belgium. ${ }^{4}$ Department of Clinical Biology, Ziekenhuis Oost-Limburg (ZOL), Genk, Belgium. ${ }^{5}$ Department of General Practice, Leuven University (KULeuven), Leuven, Belgium. ${ }^{6}$ Primary health care center GVHV, Genk, Belgium.

\section{Authors' contributions}

VP participated in the design of the study, the sample collection, KIM-1 measurements, the analyses of the data and the writing of the manuscript. LMD was involved in the sample collection and the KIM-1 measurements. EM participated in the design of the study and the sample collection. TN was involved in the design of the study and conducted the statistical analyses. EV and JR participated in the design of the study. CR carried out the routine analyses. HDW was involved in the design of the study and the sample collection. RC carried out the urinary cadmium analyses. JP and QS were both involved in the design of the study and the data analyses. All authors read and approved the final manuscript.

\section{Competing interests}

The authors declare that they have no competing interests.

Received: 1 March 2011 Accepted: 5 September 2011

Published: 5 September 2011

\section{References}

1. Nawrot TS, Staessen JA, Roels HA, Munters E, Cuypers A, Richart T, Ruttens A, Smeets K, Clijsters H, Vangronsveld J: Cadmium exposure in the population: from health risks to strategies of prevention. Biometals 2010, 23:769-82.

2. Bernard A: Cadmium \& its adverse effects on human health. Indian J Med Res 2008, 128:557-564.

3. Staessen JA, Roels HA, Emelianov D, Kuznetsova T, Thijs L, Vangronsveld J, Fagard R: Environmental exposure to cadmium, forearm bone density, and risk of fractures: prospective population study. Public Health and Environmental Exposure to Cadmium (PheeCad) Study Group. Lancet 1999, 353:1140-1144.

4. Sabolic I: Common mechanisms in nephropathy induced by toxic metals. Nephron Physiol 2006, 104:107-114.

5. Jarup L: Cadmium overload and toxicity. Nephrol Dial Transplant 2002, 17(Suppl 2):35-39.

6. Ikeda M, Ezaki T, Tsukahara T, Moriguchi J, Furuki K, Fukui Y, Ukai SH, Sakurai H: Critical evaluation of alpha1- and beta2-microglobulins in urine as markers of cadmium-induced tubular dysfunction. Biometals 2004, 17:539-541.

7. Staessen JA, Lauwerys RR, Ide G, Roels HA, Vyncke G, Amery A: Renal function and historical environmental cadmium pollution from zinc smelters. Lancet 1994, 343:1523-1527.

8. Nordberg GF, Jin T, Wu X, Lu J, Chen L, Lei L, Hong F, Nordberg M: Prevalence of kidney dysfunction in humans - relationship to cadmium dose, metallothionein, immunological and metabolic factors. Biochimie 2009, 91:1282-1285.

9. Bernard AM, Thielemans NO, Lauwerys RR: Urinary protein 1 or Clara cell protein: a new sensitive marker of proximal tubular dysfunction. Kidney Int Suppl 1994, 47:S34-37.

10. Shaikh ZA, Ellis KJ, Subramanian KS, Greenberg A: Biological monitoring for occupational cadmium exposure: the urinary metallothionein. Toxicology 1990, 63:53-62.

11. Chen L, Jin T, Huang B, Nordberg G, Nordberg M: Critical exposure level of cadmium for elevated urinary metallothionein-an occupational population study in China. Toxicol Appl Pharmacol 2006, 215:93-99.

12. Bernard A, Roels H, Buchet JP, Cardenas A, Lauwerys R: Cadmium and health: the Belgian experience. IARC Sci Publ 1992, 15-33.

13. Roels HA, Hoet P, Lison D: Usefulness of biomarkers of exposure to inorganic mercury, lead, or cadmium in controlling occupational and environmental risks of nephrotoxicity. Ren Fail 1999, 21:251-262.

14. Nakajima M, Kobayashi E, Suwazono Y, Uetani M, Oishi M, Inaba T, Kido T, Shaikh ZA, Nogawa K: Excretion of urinary cadmium, copper, and zinc in 
cadmium-exposed and nonexposed subjects, with special reference to urinary excretion of beta2-microglobulin and metallothionein. Biol Trace Elem Res 2005, 108:17-31.

15. Vincent C, Kew MC, Bouic P, Flacher M, Revillard JP: Alpha 1-microglobulin (HC protein) in human hepatocellular carcinoma. Br J Cancer 1989, 59:415-416.

16. Porstmann T, Schmechta H, Hentschel C, Doepel H, Pas P, Becker J, Pergande M, Jung K, Nugel E: Development of an immunoenzymometric assay for alpha 1-microglobulin and measurement of its serum concentration in normal and HIV-infected persons. J Clin Chem Clin Biochem 1990, 28:669-675.

17. Shikimi T, Kaku K, Uegaki J, Inagaki T, Seno H, Ishino H, Takaori S: Serum contents of the free forms of alpha(1)-microglobulin and ulinastatin: relation to diseased states in patients with mood disorders. Neuropsychobiology 2001, 43:145-149.

18. Ichimura T, Bonventre JV, Bailly V, Wei H, Hession CA, Cate RL, Sanicola M: Kidney injury molecule-1 (KIM-1), a putative epithelial cell adhesion molecule containing a novel immunoglobulin domain, is up-regulated in renal cells after injury. J Biol Chem 1998, 273:4135-4142.

19. Bailly V, Zhang Z, Meier W, Cate R, Sanicola M, Bonventre JV: Shedding of kidney injury molecule-1, a putative adhesion protein involved in renal regeneration. J Biol Chem 2002, 277:39739-39748.

20. van Timmeren MM, van den Heuvel MC, Bailly V, Bakker SJ, van Goor H, Stegeman CA: Tubular kidney injury molecule-1 (KIM-1) in human renal disease. J Pathol 2007, 212:209-217.

21. Vaidya VS, Ramirez V, Ichimura T, Bobadilla NA, Bonventre JV: Urinary kidney injury molecule-1: a sensitive quantitative biomarker for early detection of kidney tubular injury. Am J Physiol Renal Physiol 2006, 290: F517-529.

22. Amin RP, Vickers $A E$, Sistare $F$, Thompson $K L$, Roman RJ, Lawton $M$, Kramer J, Hamadeh HK, Collins J, Grissom S, Bennett L, Tucker CJ, Wild S, Kind C, Oreffo V, Davis JW, Curtiss S, Naciff JM, Cunningham M, Tennant R Stevens J, Car B, Bertram TA, Afshari CA: Identification of putative gene based markers of renal toxicity. Environ Health Perspect 2004, 112:465-479.

23. Prozialeck WC, Vaidya VS, Liu J, Waalkes MP, Edwards JR, Lamar PC, Bernard AM, Dumont X, Bonventre JV: Kidney injury molecule-1 is an early biomarker of cadmium nephrotoxicity. Kidney Int 2007, 72:985-993.

24. Zhou Y, Vaidya VS, Brown RP, Zhang J, Rosenzweig BA, Thompson KL, Miller TJ, Bonventre JV, Goering PL: Comparison of kidney injury molecule- 1 and other nephrotoxicity biomarkers in urine and kidney following acute exposure to gentamicin, mercury, and chromium. Toxicol Sci 2008, 101:159-170.

25. Liangos $\mathrm{O}$, Perianayagam MC, Vaidya VS, Han WK, Wald R, Tighiouart $H_{\text {, }}$ MacKinnon RW, Li L, Balakrishnan VS, Pereira BJ, Bonventre JV, Jaber BL: Urinary $\mathrm{N}$-acetyl-beta-(D)-glucosaminidase activity and kidney injury molecule-1 level are associated with adverse outcomes in acute renal failure. J Am Soc Nephrol 2007, 18:904-912.

26. Vaidya VS, Waikar SS, Ferguson MA, Collings FB, Sunderland K, Gioules C, Bradwin G, Matsouaka R, Betensky RA, Curhan GC, Boventre JV: Urinary Biomarkers for Sensitive and Specific Detection of Acute Kidney Injury in Humans. Clin Trans/ Sci 2008, 1:200-208.

27. Han WK, Bailly V, Abichandani R, Thadhani R, Bonventre JV: Kidney Injury Molecule-1 (KIM-1): a novel biomarker for human renal proximal tubule injury. Kidney Int 2002, 62:237-244.

28. van Timmeren MM, Vaidya VS, van Ree RM, Oterdoom LH, de Vries AP, Gans RO, van Goor H, Stegeman CA, Bonventre JV, Bakker SJ: High urinary excretion of kidney injury molecule- 1 is an independent predictor of graft loss in renal transplant recipients. Transplantation 2007, 84:1625-1630.

29. Prozialeck WC, Edwards JR, Lamar PC, Liu J, Vaidya VS, Bonventre JV: Expression of kidney injury molecule-1 (Kim-1) in relation to necrosis and apoptosis during the early stages of $\mathrm{Cd}$-induced proximal tubule injury. Toxicol Appl Pharmacol 2009, 306-314.

30. Prozialeck WC, Edwards JR, Vaidya VS, Bonventre JV: Preclinical Evaluation of Novel Urinary Biomarkers of Cadmium Nephrotoxicity. Toxicol Appl Pharmacol 2009, 238:301-305.

31. Prozialeck WC, Edwards JR: Early biomarkers of cadmium exposure and nephrotoxicity. Biometals 2010, 23:793-809.

32. Bartholomeeusen S, Kim CY, Mertens R, Faes C, Buntinx F: The denominator in general practice, a new approach from the Intego database. Fam Pract 2005, 22:442-447.
33. Chaturvedi S, Farmer T, Kapke GF: Assay validation for KIM-1: human urinary renal dysfunction biomarker. Int J Biol Sci 2009, 5:128-134.

34. Pennemans V, De Winter LM, Faes C, Van Kerkhove E, Reynders C, Rigo JM, Swennen Q, Penders J: Effect of $\mathrm{pH}$ on the stability of kidney injury molecule 1 (KIM-1) and on the accuracy of its measurement in human urine. Clin Chim Acta 2010, 411:2083-2086

35. Wu I, Parikh CR: Screening for kidney diseases: older measures versus novel biomarkers. Clin J Am Soc Nephrol 2008, 3:1895-1901.

36. Ikeda M, Ohashi F, Fukui Y, Sakuragi S, Moriguchi J: Closer correlation of cadmium in urine than that of cadmium in blood with tubular dysfunction markers in urine among general women populations in Japan. Int Arch Occup Environ Health 2010, 84:121-9.

37. WHO: Air quality guidelines for Europe. WHO Reg Publ Eur Ser 2000, V$\mathrm{X}: 1-273$

38. Kobayashi E, Suwazono Y, Uetani M, Inaba T, Oishi M, Kido T, Nishijo M, Nakagawa H, Nogawa K: Estimation of benchmark dose as the threshold levels of urinary cadmium, based on excretion of total protein, beta2microglobulin, and $\mathrm{N}$-acetyl-beta-D-glucosaminidase in cadmium nonpolluted regions in Japan. Environ Res 2006, 101:401-406.

39. Vaidya VS, Ozer JS, Dieterle F, Collings FB, Ramirez V, Troth S, Muniappa N, Thudium D, Gerhold D, Holder DJ, Bobadilla NA, Marrer E, Perentes E, Cordier A, Vonderscher J, Maurer G, Goering PL, Sistare FD, Bonventre JV: Kidney injury molecule-1 outperforms traditional biomarkers of kidney injury in preclinical biomarker qualification studies. Nat Biotechnol 2010, 28(5):478-485.

40. Payn MM, Webb MC, Lawrence D, Lamb EJ: Alpha1-microglobulin is stable in human urine ex vivo. Clin Chem 2002, 48:1136-1138.

41. Endo G, Konishi Y, Kiyota A, Horiguchi S: Urinary alpha 1 microglobulin in lead workers. Bull Environ Contam Toxicol 1993, 50:744-749.

42. Bernard A: Renal dysfunction induced by cadmium: biomarkers of critical effects. Biometals 2004, 17:519-523.

43. Vaidya VS, Ferguson MA, Bonventre JV: Biomarkers of acute kidney injury. Annu Rev Pharmacol Toxicol 2008, 48:463-493.

44. Prozialeck WC, Edwards JR: Cell adhesion molecules in chemicallyinduced renal injury. Pharmacol Ther 2007, 114:74-93.

45. Bottari E, Festa MR: On the behaviour of cysteine as ligand of cadmium (II). Talanta 1997, 44:1705-1718

doi:10.1186/1476-069X-10-77

Cite this article as: Pennemans et al:: The association between urinary kidney injury molecule 1 and urinary cadmium in elderly during longterm, low-dose cadmium exposure: a pilot study. Environmental Health 2011 10:77

\section{Submit your next manuscript to BioMed Central and take full advantage of:}

- Convenient online submission

- Thorough peer review

- No space constraints or color figure charges

- Immediate publication on acceptance

- Inclusion in PubMed, CAS, Scopus and Google Scholar

- Research which is freely available for redistribution

Submit your manuscript at www.biomedcentral.com/submit
C Biomed Central 